\title{
Bibliography as Anthropometry: Dreaming Scientific Order at the fin de siècle
}

\section{Citation}

Csiszar, Alex. 2013. Bibliography as Anthropometry: Dreaming Scientific Order at the fin de siècle. Library Trends 62, no. 2: 442-455.

\section{Published Version}

doi:10.1353/lib.2013.0041

\section{Permanent link}

http://nrs.harvard.edu/urn-3:HUL.InstRepos:11992784

\section{Terms of Use}

This article was downloaded from Harvard University's DASH repository, and is made available under the terms and conditions applicable to Other Posted Material, as set forth at http:// nrs.harvard.edu/urn-3:HUL.InstRepos:dash.current.terms-of-use\#LAA

\section{Share Your Story}

The Harvard community has made this article openly available.

Please share how this access benefits you. Submit a story. 


\title{
Bibliography as Anthropometry: Dreaming Scientific Order at the fin de siècle
}

\author{
Alex Csiszar
}

\begin{abstract}
The 1890s saw an explosion of ambitious projects to build a massive classification of knowledge that would serve as a basis for universal catalogues of scientific publishing. The largest of these were the rival International Catalogue of Scientific Literature (London) and Répertoire Bibliographique Universel (Brussels). This essay argues that one widely influential but overlooked source of the enthusiasm for classification as a technology of search and retrieval during this period was the emergence of new methods and technologies for classifying and keeping track of people, and in particular, the criminal identification laboratory of Alphonse Bertillon located in Paris.
\end{abstract}

John Shaw Billings, the doctor, medical bibliographer, and founding director of the New York Public Library, traveled to London in July 1896 to head the American delegation at the first of a series of London conferences to build an International Catalogue of Scientific Literature. In his toast at the opening banquet, he speculated that if the gathered delegates were completely successful in building the hoped-for Catalogue, "they might anticipate a time when men and things and thoughts also would be cataloged":

They might look forward down the vista of years to the time when a stranger in Hyde Park would see a passer-by with such a number as 26.053 , and would then at once appreciate his status in every respect, and when the novelist would proudly show that his heroine had 26 points in her character, while a rival writer had only achieved 19. (International Catalogue Conference, 1896, p. 250)

Though Billings's classificatory fantasy of a world in which all individuals-whether real or fictional-had their place in a massive database was certainly tongue-in-cheek, it raises important historical questions. What 
made it possible for this collection of scientists and bibliographers purportedly focused on the journal literature of science to imagine their enterprise in terms of the classification of people? What can this tell us about what they thought they were trying to accomplish?

During the 1890s a tenacious nineteenth-century European obsession reached its apex. Classifications of knowledge, and of science especially, were everywhere, gaining the attention not only of philosophers but of scientists, librarians, and even internationalist lawyers. Aside from their ubiquity, this moment was also distinguished by several ambitious attempts to operationalize such classificatory schemes in massive, often international, cataloguing enterprises. Classifying the sciences was to be made a social technology of scientific order.

It is easy to suppose that the rise of these projects was a rational response to the explosive growth of the scientific literature that occurred during the second half of the nineteenth century (led by scientific periodicals). Certainly, there was no lack of scientists who bemoaned the runaway growth of journals, the hazards of drowning in print, and the potential for knowledge to disintegrate in chaos (Csiszar, 2010a). But as historical explanation, the information overload argument comes up short. First, the purported cause is not equal to the specificity of the response; it is not obvious that the best way to deal with the literature problem should have been grandiose subject classification projects. Other more traditional—some might say more sensible—options existed: better specialized disciplinary bibliographies, expanded alphabetical subject indexes, or even relying more on the accumulated knowledge of recognized experts. (Indeed, given the ultimate failure of many of these projects, it might plausibly be argued that in hindsight universal and detailed classification was a misguided approach.) Second, such an explanation also demands a better characterization of what made this crisis of information special; as historians such as Ann Blair have shown, savants have lamented the crush of information from at least the invention of printing onward (Blair, 2010; Rosenberg, 2003). Why classification? Why the fin-de-siècle?

To understand the enthusiasm for scientific bibliography requires looking beyond internal needs of the sciences for more efficient communication. The classificatory turn was part of a broader culture of classificatory enthusiasm that reigned during the decades around 1900. This enthusiasm was evident across several sciences (not simply natural historical fields, but mathematics, sociology, philosophy, and others), and went beyond them as well). Perhaps the most celebrated classificatory practice of the era originated not in the natural sciences at all but in the pursuit of criminals. In this essay I argue that it is here-specifically in the identification laboratory of the Parisian Police-that we should look to better understand the motivations and inspiration of bibliographer-scientists at the turn of the century. 


\section{From ANTHropometry to Bibliography}

The London conference for which Billings made his classificatory toast had been convened by the Royal Society of London. The self-styled oldest scientific society, in connection with the Foreign Office, had gathered together delegates of several nations and British colonies to begin to forge an international agreement as to how to reorganize the scientific world in print. It was the first of several conferences in London leading to the inauguration of the International Catalogue of Scientific Literature, which finally became operational in 1901. While the main office of the Catalogue was in London, there were regional bureaus scattered across Europe, many British colonies, North America, and Japan. The Catalogue, in book form, covered seventeen branches of science and was distinguished by an incredibly elaborate subject classification that had been pieced together by expert committees of scientists and bibliographers beginning in 1896 (Fuchs, 2004; Csiszar, 2010a, pp. 350-425). But this massive venture was just one prominent instance of a broader movement. Among the Royal Society's major competitors was a group based in Belgium called the Institut International de Bibliographie, inaugurated in1895 by internationalist lawyers Paul Otlet and Henri La Fontaine (Rayward, 1975; Rayward, 2010). Although the scope of their Répertoire Bibliographique Universel encompassed far more than the natural sciences, and the motivations of Otlet and La Fontaine had as much to do with international peace as scientific organization, the overlap was enough to produce massive tensions. Especially prominent was that while both groups wanted to construct an elaborate subject classification of all scientific knowledge, they utterly disagreed about how to go about doing so. The Institut International in Brussels early on decided that the decimal system of the American Melvil Dewey would be the basis of their future triumph. The system was expandable, stable but flexible, and international. True, Dewey's classification was not "scientifically accurate," but what stable system could ever be so? A usable standard was needed, and Dewey would do well as the basis for an expanded universal classification of all knowledge.

Billings's use of decimal call numbers in his fantasy of total classification was a transparent allusion to Dewey's system. Decimals were looming ever larger in European discussions regarding the problem of bibliography. The interest in Dewey was driven by Otlet and La Fontaine, but there were others who were independent promoters of the system in England (Rayward, 1983), and the Belgians were attracting adherents to the cause across Europe. The Royal Society itself had begun experimenting with classification in 1894, and their Oxford cataloguing consultant, George Burch, had recommended giving Dewey a try. Indeed, the preliminary classification schemes that they worked out started from a slight alteration of the Dewey system. Their first attempt looked like this; here, the only 
major change from Dewey's classification of the natural sciences is that Palaeontology is replaced by physiology. ${ }^{1}$

500 Natural Science

510 Pure Mathematics

520 Astronomy

530 Physics (including Meteorology and Crystallography)

540 Chemistry

550 Geology

560 Zoology

570 Botany

580 Physiology

590 Ethnology

But for all its grandeur, little about Dewey decimals implied the classification of people, or even the broader philosophical ambitions that European cataloguers seemed to entertain. Dewey himself warned the Royal Society against getting carried away with their classifications:

Science will never stand still and a classification is only a great series of pigeon-holes in which to file papers. The man who insisted on tearing his desks and study to pieces every few years and grouping the pigeonholes over again would be looked upon as a little lacking in balance. If our friends could recognize that a classification for practical use by a great body of people was really like a great set of pigeon-holes, and not try to have it meet all their philosophical theories, we should get over the greatest difficulty, for my study long ago convinced me that the philosophical side of the classification was a minor consideration. ${ }^{2}$

Dewey's advice was that keeping science in order was basically like keeping the desk of a man of business organized, so that whatever they did, they should avoid getting philosophical. But Dewey was not optimistic; could a summit stocked with eminent European scientists hold themselves back from the metaphysical temptations that had foiled so many classifiers? "I am fearful from some of the discussion I have seen, that the conference may be led off on questions of philosophical or scientific accuracy," he wrote to the Society, "and that the experiments and corrections will develop a degree of impatience, if not actual disgust, that will lead to wrecking the entire plan." ${ }^{3}$ Dewey's prediction turned out to be at least partly correct: the question of classification was the focus of countless disputes for years, not simply between advocates of the rival projects, but internally among adherents of each project as well, and nearly led to both projects' premature demise on several occasions.

How to explain the peculiar flavor of the classifying debate in Europe circa 1896? The pragmatism of Dewey's system and hardware-he had also founded the Library Bureau to sell the equipment with which to do 
the classifying (Wiegand, 1996, pp. 70-71, 234-242)-was by no means the only imaginative resource the would-be bibliographers drew on. The influence of Dewey merged not only with the powerful philosophical tradition of classifying knowledge but with an equally compelling classification system that had just taken Europe by storm: this was the criminoanthropometric system built by the French criminologist Alphonse Bertillon (Cole, 2001, 32-59; Sekula, 1986; Cochart, Haroche, \& Bonnet, 1987).

By the 1890s, Alphonse Bertillon had become well known across Europe for his pioneering scheme to identify recidivists by cataloguing physical descriptions of convicts. His father, Louis-Adolphe Bertillon, had been a well-known anthropologist; the school of French anthropology had long worked with human measurement techniques and instruments in their attempts to establish an (ever-elusive) objective classification of human races (Blanckaert, 2001; Wartelle, 2004). Alphonse had one day hit upon the idea that something similar might be used to classify, and thus identify, individuals for more immediately practical purposes. While police in other cities had developed routines for recording the physical traits and peculiarities of criminals, what was important about Bertillon's system was that he developed a scheme of classification that allowed, in principle, for speedy retrieval of records. As he put it himself, "the solution to the problem of judicial identification consists less in finding new identifying characteristics of individuals than in the discovery of a method of classification" (Bertillon, 1893a, xv).

According to Bertillon's method, a set of nine (later eleven) standard measurements was taken of an individual's body and each measure was categorized according to some discrete scheme (often short-medium-long). The information was placed on an identification card, along with a detailed physical description and photographs, and then filed in the card archive according to a place determined by the results of those several measurements. Given a set of measures, an investigator could inspect precisely those cards which matched the profile and check for a matching photograph or physical description (the so-called portrait parlê). Rather than searching through thousands of photographs and files, search might be limited to a few dozen or less. This allowed, Bertillon claimed, for a fast and reliable determination of whether a given individual had been previously arrested. (fig. 1 shows a rendering of the casiers used to store Bertillon's fiches.)

Bertillon's alleged success in identifying repeat offenders for the Paris police caused his name to spread widely. Anthropometric laboratories sprang up in Europe, North and South America, and even Japan (Mansuy \& Mazliak, 2011). In England, Francis Galton applied the same technique of search and retrieval but focused all measurements on the character of an individual's fingertips. Galton also elaborated a general statistical theory of classification to explain the inadequacies of Bertillon's own system in comparison with his own. ${ }^{4}$ 


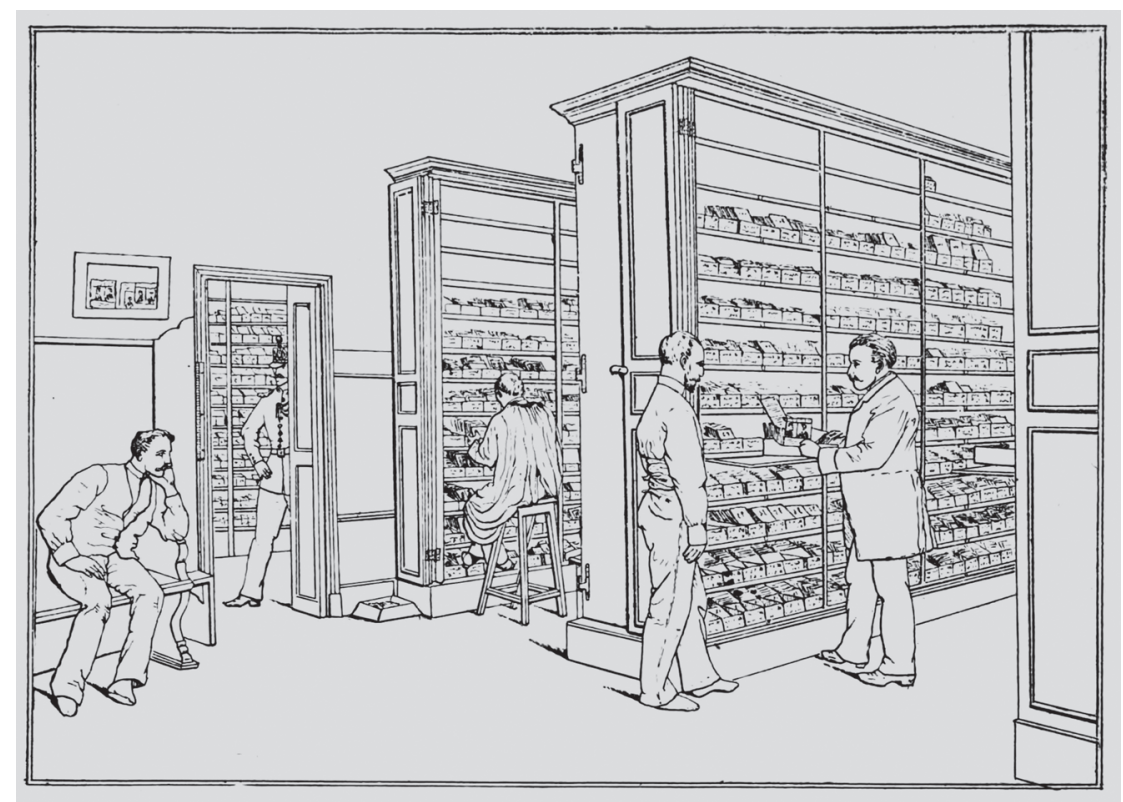

Figure 1. Rendering of the file room in the Paris criminal identification laboratory. Source: L'anthropométrie judiciaire à Paris en 1889 (Lyon: A. Storck, 1890, p. 13).

Fingerprinting ultimately overtook Bertillonage as the method of choice in criminal identification, but not before Bertillon himself became something of a household name. His fame reached beyond the problem of recidivism and was, for a time, emblematic of the power of classification as a general science of search, retrieval, and surveillance. As early as 1885, in remarks that were translated into both English and German, Louis Herbette, chief of the French system of penitentiaries, suggested that Bertillon's system might serve modern states as the basis for a comprehensive system of personal identification. He suggested they might "give to the inhabitants of a country, to the soldiers of an army, to travelers in distant lands, individual records or cards, identifying marks allowing for a determination or proof of who they are in any situation." (Bertillon, 1887, 298). He also pointed out potential uses in regulating life insurance policies, in identifying those who had suffered injuries, or in keeping tabs on those whose had fallen into insanity. Bertillonage would "fix the human personality, giving every human being an identity, an individuality that is certain, durable, invariable, always recognizable, and which can be established with ease" (Bertillon, 1887, p. 299). Over the next decades, several states did develop identification practices of just this sort (Kaluszynski, 2001; Kaluszynski, 2002). The French, for example, eventually established a system directed at containing the movements of nomadic populations (the Carnet 
anthropométrique of 1912 [Filhol, 2011]), while the U. S. Army adopted a version of Bertillonage as a means of identifying soldiers (Alden, 1901).

The public celebrity of Bertillonage within and outside of France reached its peak beginning in 1893. That year, his criminal identification service was given a prominent place in the French pavilion at the World's Columbian Exhibition in Chicago (Bertillon, 1893b). Periodicals across Europe and America published excited, sometimes sensational, reports on the celebrated new "Science of Identification" (Vincent, 1894, p. 73; Spearman, 1893; Tarbell, 1894) that was thriving in Paris and elsewhere. That same year, Arthur Conan Doyle had Sherlock Holmes and Dr. Watson discussing "the Bertillon system of measurements," with Holmes expressing "his enthusiastic admiration of the French savant" (Conan Doyle, 1893 , p. 460). Bertillon was becoming a household name.

It is at just this moment that scientists began to discuss in earnest the possibility of building massive bibliographical catalogues of scientific literature. In March 1894, the Royal Society deployed a circular to scientific institutions across the world to gauge their interest in cooperating on an international catalogue of science. The chemist Henry Edward Armstrong took a leading role in promoting the plan. In his Presidential Address to the Chemical Society of London that month, he argued that an international, classified catalogue of science was not only sorely needed but wholly feasible. To make his case, he appealed not to previous bibliographical enterprises but to Bertillonage: "We are told that by the Bertillon system, dealing with the card records of 90,000 convicts, it is possible ... to ascertain whether a prisoner has been before convicted . . with considerable, if not absolute, confidence." Once measurements are taken, "his card will be found in a drawer containing only about 400. Surely, we ought to be able to devise a system which would equally limit our search" (Armstrong, 1894, p. 366).

Problems of search and retrieval in the sciences did seem to present analogies to the problem of recidivism. Natural historians, in particular, were tormented by the scourge of synonymy, whereby plant and animal species were constantly being rediscovered and renamed, in part because collectors had no systematic means of confirming that the specimens they turned up had not already been described. How to be sure what was already known (Csiszar, 2010b; Daston, 2004)? Paul Otlet, director of the Institut international de bibliographie, though he disagreed with Armstrong and the Royal Society on so many points regarding the nature of classification, did agree that Bertillonage was among the most important precursors of their enterprise. In promoting the advantages of the decimal system, he drew on Bertillonage to illustrate the central concept of his own enterprise: 
Decimal classification thus constitutes a perfect method for organizing materials for retrieval [localisation]. It is not without analogy to the system of anthropometric identification devised by M. Bertillon and which is in place in the great capitals of Europe to general approval. It corresponds to this essential principle of bibliographical ordering: a place for everything and everything in its place. It is, moreover, a rational arrangement: this idea is indeed the essence of the system. (Otlet and La Fontaine, 1895, p. 30)

Where Armstrong and the Royal Society overstepped by attempting to invent a scientific classification, Otlet was inspired by Bertillon to imagine the general practice of classification itself as a science. ${ }^{5}$

Otlet not only promoted the parallels between bibliography and criminal identification but took steps to enroll Bertillon himself as a collaborator in his burgeoning movement. He first wrote to Bertillon in late 1895 after writing the above piece, to inquire what Bertillon thought about the striking parallels he had described. ${ }^{6}$ The next spring, he paid a visit to Bertillon's anthropometric laboratory at the Paris Prefecture of Police to learn from the master himself. He reported being stunned by the "mathematical precision" of Bertillon's operation, which he could only hope would rub off on his own cataloguing enterprise. He also attempted to convince Bertillon that his system could be made even more efficient by being reworked in terms of decimals. Each division into short/medium/long would correspond to numbers $(1 / 2 / 3)$ and then linked together in a standard order. He gave a suggestion for how this translation might be done: ${ }^{7}$

$\begin{array}{lll}\text { Chiffre du 1er rang Longueur de tête } & -184 & 1 \\ & 185-190 & 2 \\ & 191- & 3 \\ \text { Chiffre du 2e rang Largeur de tête } & \text { Petite } & 1 \\ & \text { Moyenne } & 2 \\ & \text { Grande } & 3 \\ \text { Chiffre du 3e rang Longueur du Medius } & \text { Petit } & 1 \\ & \text { Moyen } & 2 \\ & \text { Grand } & 3 \\ \text { Chiffre du 8e rang Couleur de l'oeil } & & \\ & \text { a } & 1 \\ & \text { b } & 2 \\ & \text { c } & 3 \\ & \text { d } & 4 \\ & \text { e } & 5 \\ & \mathrm{f} & 6 \text { bleu } \\ & \text { g } & 7 \\ & \text { h } & 8\end{array}$

A number such as 213.132.26, then, "would correspond to the index card of individuals who fell into the following divisions": 


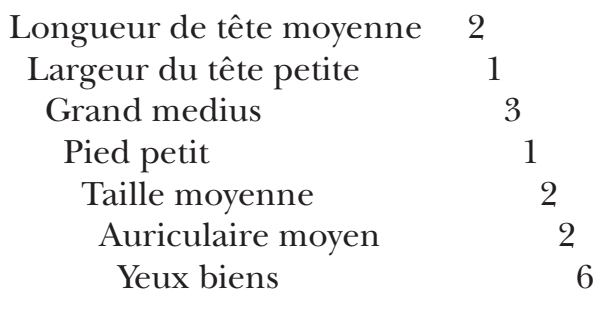

Soit 213.132.26.

Otlet argued that such a system would make for a more efficient and natural way to keep the index cards in order, and would provide flexibility to extend the system if new measurements were added to it in the future. Otlet's decimalization of Bertillonage did not amount to much more than a cosmetic change in record keeping, but it was symptomatic of a strong desire to bring compatible systems of ordering to as wide a variety of activities as possible, from scientific objects, to bibliography, to human beings.

Bertillon himself was not as convinced of the universal applicability of the decimal system. It was precisely the drive for maximum precision alluded to by Otlet that he objected to: "anthropometric measures cannot be recorded with absolute precision, since there is always a gap of approximation between the figures recorded at different times on the same individual." Despite the bibliographers' fantasies, anthropometry in practice actually depended on imprecision, for unlike documents, people might change over time, and there was a danger that the same individual might end up being assigned more than one decimal number. ${ }^{8}$ Bertillon was proud of the extension of his system to the identification of people and citizens in general, but that was as far as he was willing to go. He thus rejected one of the key implicit assumptions that drove Otlet and his allies in their quest for universal bibliographical order, that there was a science and practice of classification that transcended its particular applications. While Otlet himself accepted that bibliographical classification, being conventional, could not be expected to be philosophically accurate, he nevertheless believed that classification itself ought to be viewed as a science, in the sense that there were systematic principles and procedures underlying its correct practice.

\section{The Discovery of Literary Identities}

Another Parisian correspondent of Otlet's, Marcel Baudouin, was more optimistic about the potential for classificatory synergy. An on-again-offagain ally of Otlet's, Baudouin was an information services entrepreneur. In 1895, independent of both Otlet's Institut and the Royal Society, he founded an office in Paris called the Institut de Bibliographie Scientifique, which he hoped would become a one-stop shop for scientific infor- 
mation in France (Csiszar, 2010a, pp. 417-425). The Institut purported to include a circulating library for scientific publications, a copying service, on-demand translation, and even an outfitter of personal scientific libraries. But its focus was its bibliographical card service. The Institut's staff would classify new scientific books and articles as they were received, and would write up index cards that they would send to subscribers based on their particular disciplinary interests. Like Otlet, Bertillon's classification also began from Dewey, though to Otlet's dismay he insisted on tampering with certain basic characteristics of the system.

Inspired by the American Index Medicus associated with John Shaw Billings, Baudouin began by focusing on medical literature, with plans to branch out to other branches of science as his staff and revenue grew. Baudouin was by no means the only one offering such a service to scientists at around that time, and his business did not last a decade, but he may have been the most ambitious. He claimed that his process could instantaneously provide doctors and scientists with "the most complete, most perfect bibliographical documents available anywhere" (Baudouin, 1895, pp. 708-709).

In 1898, at the height of his business's success, Baudouin sought to branch out with a new service: identifying the authors of anonymous scientific publications. In announcing his new plan, Baudouin noted that among his classified archive, he had already gathered together two thousand anonymous pieces (Baudouin, 1898, p. 650). As scientific publishing had come increasingly to embrace the standard format of the authored scientific paper, the existence of anonymous articles was increasingly seen as an anomaly, a threat to scientific responsibility and to bibliographical order. Baudouin took his language directly from Bertillonage, describing an elaborate method for the "Rapid Discovery of Literary Identity" by the use of special bibliographical directories. He claimed that through his system, the author of an anonymous work, or at least his personality, could be revealed "by studying, not the length of his humerus or his fingers, nor his photographic silhouette, but the reduction to cards, you might almost say photographically, of his works and their principal external traits" (Baudouin, 1898, p. 655).

Baudouin carefully laid out the various cases of author-less texts one might be faced with: works that had single authors (Monoanonymes), those that had multiple authors in which individual sections were written individually (Polyanonymes faux), multiauthor works written on behalf of some organization, such as a government body (Polyanonymes vrais), and works in which authorship had been partially revealed, through initials (Anonymes à initiales) (Baudouin, 1898, pp. 651-653).

He sketched out a classificatory scheme according to form of publication, place, journal venue (if applicable), subject/discipline, chronology (broken up in twenty-five-year segments), and, finally, style. In fact, it was 
the latter that seemed to capture the spirit of Baudouin's hopes: while his scheme began with bibliographical data, it progressed, via the analysis of style, toward identifying and thus categorizing types of scientific authors. Even when names were out of reach, personality types might still be found, with the right sort of detective work. In this conception, bibliometrics was not simply analogous to the successes of criminal anthropometry, but became a form of anthropometry itself:

The anthropometrician classifies the human body; The Bibliographer who deals with anonymous works classifies not so much the brains of men, but in some sense the photographic traces of the functioning of their brains, that is to say, the productive works of their intelligence. (Baudouin, 1898, p. 655)

As it happened, Alphonse Bertillon himself had entered the business of literary identification through the graphical analysis of handwriting (Bertillon, 1897). Baudouin's bibliographical anthropometrics would take the natural next step by pursuing a textual forensics of the mind.

There is no evidence that Baudouin got very far in this ambitious new enterprise. The success of his Institut was reaching its peak at the time he drafted the plan; the next year he took over the production of the Index Medicus when its American funding lapsed (Kunz, 1979), which presumably left little time to develop his literary identity service. But the prospects of his organization gradually declined, and Baudouin was out of business a few years into the new century. Still, his plan to make bibliography into a spiritual anthropometry was the most elaborate statement of a widespread idea. It was, after all, the famous founder of the Index Medicus, John Shaw Billings, who dreamed of a "time when a stranger in Hyde Park would see a passer-by with such a number as 26.053 , and would then at once appreciate his status in every respect."

\section{Of Men And Things And Thoughts}

Classifications of science, both philosophical and bibliographical, reached a frenzied peak in the decades surrounding 1900 , led by the two massive international cataloguing projects of the Royal Society and the Institut International de Bibliographie. Imagining categories that flitted back and forth between people and documents was a widespread phenomenon, and indeed was an island of tacit consensus in a sea of bibliographical discord. Why?

Histories of early information science have tended to tell of the emergence of this new profession as having occurred when bibliographical pioneers finally threw off the shackles of metaphysics and took full possession of bibliographical classification as a practical tool with its own theoretical foundations. In this vision, Melvil Dewey is a crucial forerunner, 
and his European disciples are founding figures (Rayward, 1998). But the story turns out to be rather more complex. The enthusiasm for bibliographical classification was part of a broader enthusiasm for classification that saw the merger of the philosophical problem of classification and the practical problem of the organization of documents in a new empirical problem that swallowed both traditions. Dewey, the efficiency-loving American, was one of many sources. The anthropometric imaginary was another. In fact, the popularity of the latter among the bibliographers, I believe, went deeper than the high reputation of Bertillon's crime laboratory. For the debates about how to catalogue science were, in fact, as much about how to group and organize people as they were about how to organize documents. The scientific enterprise was just coming into view as a social enterprise itself, one that might be governed by its own regularities and evolutionary laws. Classifying the literary output of science might be a means of gaining an empirical handle on this social evolution. A few years later, the American logician Charles S. Peirce stated the idea best when he outlined his own plans for a classification of science: "My notion is that what we call 'natural classification' is, from the nature of things limited to natural objects. ... What is a science as a natural object? It is the actual living occupation of an actual group of living men." When scientists and bibliographers convened in 1896 to discourse of catalogues and of call numbers, their thoughts turned to science as a natural object in just this sense.

\section{Notes}

1. International Catalogue Committee Minutes, 23 January 1896. Archives of the Royal Society of London, CMB 33.

2. Letter from Melvil Dewey to Henry Armstrong, 26 June 1896. Archives of the Mundaneum (Mons), HLF 140.

3. Letter from Melvil Dewey to Henry Armstrong, 26 June 1896. Archives of the Mundaneum (Mons), HLF 140.

4. The Risk of Misclassification. (Manuscript draft of a talk given in 1899). Special Collections of University College London, Papers of Francis Galton 156. See also Galton (1893).

5. Otlet repeated the analogy between bibliography and Bertillonage as late as 1934 (Otlet, 1934, p. 287), citing its expansion into a "universal system of identification."

6. Letter from Paul Otlet to Alphonse Bertillon, ca. October 1895. Archives of the Mundaneum (Mons), APM Courrier 0303.

7. Letter from Paul Otlet to Alphonse Bertillon, 23 April 1896. Archives of the Mundaneum (Mons), APM Courrier 0302.

8. Letter from Alphonse Bertillon to Paul Otlet, 2 May 1896. Archives of the Mundaneum (Mons), APM Courrier 0301. It appears that Bertillon may have misunderstood what Otlet was suggesting, since his suggesting of a decimal translation amounts only to a cosmetic change to Bertillon's system.

9. C. S. Peirce, Adirondack Summer School Lectures (1905). Houghton Library, Harvard University MS 1334. That Peirce had bibliography in mind even for his philosophical project is clear; he cited as his authority on modern classifications the head of Princeton University Library, Ernest Cushing Richardson, who had written an exhaustive treatise on theoretical and practical classifications of science, while arguing against the view that these two approaches toward classification should or could be kept distinct. 


\section{REFERENCES}

About, I. (2004). Les fondations d'un système national d'identification policière en France (1893-1914): Anthropométrie, signalements et fichiers. Genèses, 54, 28-52.

Alden, C. H. (1901). The U. S. Army System of Personal Identification. Boston Medical and Surgical Journal, 145(November 7), 513-518.

Armstrong, H. E. (1894). Presidential address. Journal of the Chemical Society (Transactions), 65, 336-382.

Baudouin, M. (1895). Le problème bibliographique. Revue scientifique, 4, 708-15.

Baudouin, M. (1898). La découverte rapide de l'identité littéraire à l'aide du Répertoire Bibliographique "onomastique" des Anonymes. Revue scientifique, 9, 648-56.

Bertillon, A. (1887). De l'identification par les signalements anthropométriques. Bulletin de la Société générale des prisons, 11(March), 272-299.

Bertillon, A. (1893a). Identification anthropométrique: Instructions signalétiques. Melun: Imprimerie Administrative.

Bertillon, A. (1893b). Service d'identification: Exposition universelle de Chicago. Paris: Préfecture de Police Préfecture de Police.

Bertillon, A. (1897-1898). La comparaison des écritures et l'identification graphique. Revue scientifique, 9(December 18, 1897), 769-783; 10(January 1, 1898), 1-9.

Blair, A. M. (2010). Too much to know: Managing scholarly information before the modern age. New Haven: Yale University Press.

Blanckaert, C. (2001). La crise de l'anthropométrie: Des arts anthropotechniques aux dérives militantes (1860-1920). In C. Blanckaert (Ed.), Les politiques de l'anthropologie: Discours et pratiques en France (1860-1940) (pp. 95-172). Paris: Harmattan.

Cochart, D., Haroche, C., \& Bonnet, P. (1987). De l'anthropologie à l'anthropométrie: De l'identité à l'identification. In C. Blondel et al. (Eds.), Studies in the history of scientific instruments (pp. 251-258). London: Rogers Turner Books.

Cole, S. A. (2001). Suspect identities: A history of fingerprinting and criminal identification. Cambridge, MA: Harvard University Press.

Conan Doyle, A. (1893, November). The adventure of the Naval Treaty. The Strand Magazine, 459-468.

Csiszar, A. (2010a). Seriality and the search for order: Scientific print and its problems during the late nineteenth century. History of Science, 48, 399-434.

Csiszar, A. (2010b). Broken pieces of fact: The scientific periodical and the politics of search in nineteenthcentury France and Britain. Unpublished doctoral dissertation. Cambridge, MA: Harvard University.

Daston, L. (2004). Type specimens and scientific memory. Critical Inquiry, 31, 153-182.

Filhol, E. (2011). Le carnet anthropométrique des nomades. In P. Piazza (Ed.), Aux origines de la police scientifique: Alphonse Bertillon, précurseur de la science du crime (pp. 252-274). Paris: Karthala.

Fuchs, E. (2004). The International Catalogue of Scientific Literature as a mode of intellectual transfer: Promises and pitfalls of international scientific co-operation before 1914. In C. Charle and J. Schriewer (Eds.), Transnational intellectual networks: Forms of academic knowledge and the search for cultural identities (pp. 165-19). Frankfurt: Campus.

Galton, F. (1893). On Bertillonage. Nature, 48, 222.

International Catalogue Conference. (1896). Nature, 54, 248-50.

Kaluszynski, M. (2001). Republican identity: Bertillonage as government technique. In J. Caplan \& J. Torpey (Eds.), Documenting individual identity: The development of state practices in the modern world (pp. 123-138). Princeton: Princeton University Press.

Kaluszynski, M. (2002). La république à l'épreuve du crime: La construction du crime comme objet politique, 1880-1920. Paris: L.G.D.J.

Kunz, J. (1979). Index Medicus: A century of medical citation. JAMA, 241, 387-390.

L'anthropométrie judiciaire à Paris en 1889. (1890). Lyon: A. Storck.

Mansuy, R., \& Mazliak, L. (2011). L'analyse graphologique controversée d'Alphonse Bertillon dans l'Affaire Dreyfus. Polémiques et réflexions autour de la figure de l'expert. In P. Piazza (Ed.), Aux origines de la police scientifique: Alphonse Bertillon, précurseur de la science du crime (pp. 354-372). Paris: Karthala.

Otlet, P. (1934). Traité de documentation: Le livre sur le livre, théorie et pratique. Brussels: Editiones Mundaneum. 
Otlet, P., \& La Fontaine, H. (1895). La création d'un Répertoire Bibliographique Universel. Bulletin de l'Institut international de bibliographie, 1 (1895-1896), 15-38.

Rayward, W. B. (1975). The universe of information: The work of Paul Otlet for documentation and international organisation. Moscow: International Federation for Documentation.

Rayward, W. B. (1983). The early diffusion abroad of the Dewey decimal classification: Great Britain, Australia, Europe. In G. Stevenson \& J. Kramer-Greene (Eds.), Melvil Dewey: The man and the classification (pp. 149-173). Lake Placid, NY: Forest Press.

Rayward, W. B. (2010) (Trans. \& Adapt.). The origins of information science and the International Institute of Bibliography/International Federation for Information and Documentation (FID). In B. Hahn and M. K. Buckland (Eds.), Historical studies in information science (pp. 289-300). Medford, NJ: Information Today, for the American Society for Information Science and Technology.

Rayward, W. B. (Trnas. \& Adapt.). Mundaneum: Archives of knowledge. (Occasional paper no. 215). Urbana-Champaign, IL: University of Illinois Graduate School of Library and Information Science.

Rosenberg, D. (2003). Early modern information overload. Journal of the History of Ideas, 64, 1-9.

Sekula, A. (1986). The body and the archive. October, 39(Winter), 3-64.

Spearman, E. R. (1893). Criminals and their detection. The New Review, 4.50(July), 65-84.

Tarbell, I. M. (1894, March). Identification of criminals. McClure's Magazine, 355-369.

Vincent, H. (1894). Measurement identification of criminals. The English Illustrated Magazine, $12,73-76$.

Wartelle, J.-C. (2004). La Société d'anthropologie de Paris de 1859 à 1920. Revue D’histoire des Sciences Humaines, 10, 125-171.

Wiegand, W. (1996) Irrepressible reformer: A biography of Melvil Dewey. Chicago: American Library Association.

\footnotetext{
Alex Csiszar studies the history of scientific authorship, publishing, and informationmanagement practices. He is currently completing a book on the origins of the scientific journal in France and Britain, which asks how a more or less unified format coalesced out of a plethora of sundry periodical genres to become the crucial institution through which to demarcate who was and who was not a scientist, and what could and could not count as authoritative knowledge. Csiszar is an assistant professor in the Department of the History of Science at Harvard University.
} 